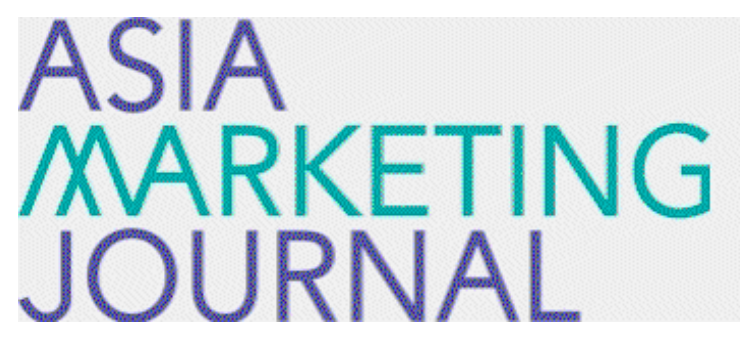

ASIA MARKETING JOURNAL

Volume 18 | Issue 3

Article 5

10-31-2016

\title{
Why Consumers Use Mobile Commerce?
}

Sang-Lin Han

T. P. Thao Nguyen

V. Anh Nguyen

Follow this and additional works at: https://amj.kma.re.kr/journal

Part of the Marketing Commons

\section{Recommended Citation}

Han, Sang-Lin; Nguyen, T. P. Thao; and Nguyen, V. Anh (2016) "Why Consumers Use Mobile Commerce?," Asia Marketing Journal: Vol. 18 : Iss. 3 , Article 5.

Available at: https://doi.org/10.15830/amj.2016.18.3.65

This Article is brought to you for free and open access by Asia Marketing Journal. It has been accepted for inclusion in Asia Marketing Journal by an authorized editor of Asia Marketing Journal. 


\title{
Why Consumers Use Mobile Commerce? - International Comparative Study of M-Commerce Model
}

\author{
Sang-Lin Han* \\ T. P. Thao Nguyen** \\ V. Anh Nguyen***
}

Development of information and communication technology is changing commerce environment and consumer purchasing behavior has also been changed.

Globalization is becoming increasingly prevalent in the world today and many factors such as culture, politics, and economics may influence the applicability of management theories. Concurrently, corporate managers are faced with the challenge of offering usable and useful applications to the local users. Besides, many scholars strongly support that the criteria for M-Commerce adoption in developing countries are different from that of developed countries, due to cultural, security, social, political, economic, and technological aspects. This research tried to investigate the differences on the adoption of mobile commerce between developed and developing countries.

In this study, the motivation for studying advanced mobile phone services adoption in the South Korea and Viet Nam is presented. Second, M-Commerce adoption model is introduced as a starting point for the research model. We then integrate price, personal innovativeness, quality dimension and perceived of playfulness into our model. Next, we describe our method and report the results of our analysis. The paper concludes with a discussion of the results from both the South Korea and Viet Nam with implications.

Key words: Mobile Commerce, Personal Innovativeness, TAM, Perceived Usefulness, Perceived Playfulness

Professor, School of Business, Hanyang University, Seoul 04763, Korea (slhan@hanyang.ac.kr)

** Faculty of Economics and Business Administration, Dalat University, Viet Nam Doctoral Candidate, Hanyang University, Korea (thaonguyendhdl@gmail.com)

*** Faculty of Economics and Business Administration, Dalat University, Viet Nam Doctoral Candidate, Hanyang University, Korea (vananhdhdl@gmail.com) 


\section{Introduction}

Nowadays, mobile commerce (M-Commerce) is seen as the new business model and platform that will have a significant impact on the business communities and industries. M-Commerce offers extra functionality to existing e-commerce such as location and localization services (Junglas \& Watson, 2008). Mobile communication technologies have penetrated into consumer markets throughout the world (Mao et al., 2005). According to ABI Research, M-Commerce will grow into a $\$ 119$ billion of global industry by 2015, up from $\$ 18.3$ billion in 2008 (Khalifa et al., 2012).

Furthermore, the increase in M-Commerce is fueled by an unstop development of new mobile smart devices and the increasing number of people who own mobile phones. Mobile phones have become important personal devices for listening to music, watching videos, playing games, conducting business transactions, and connecting to social networking sites. The interactions between consumers and their mobile phones have presented opportunities for organizations to use $\mathrm{M}$-Commerce to personalize services to customers. Realizing these opportunities, companies have been focused in MCommerce infrastructure, services and devices investment.

However, technology development and MCommerce development are seriously challenged when users hesitate or to be slow to adopt the new technology. Enhanced functionality and greater levels of mobile services require an indepth understanding of consumer perceptions and behavior. Also, by understanding deeply about the individual differences in M-Commerce adoption, telecommunications firms may formulate suitable strategies that appeal specific segments of consumer. In addition, marketers have released advanced mobile phone services, such as picture mail, internet mail, Internet browsing, and messaging that enable M-Commerce and mobile advertising (Stafford \& Gillenson, 2003). Hence, according to Nysveen et al., (2005) it is very vital for marketers, researchers as well as service providers to research about the factors that affect to behavior of consumers in M-Commerce adoption and the behavioral M-Commerce adoption requirements of these services. Therefore, the first objective of this paper is investigating the antecedents that affect the M-Commerce adoption in the developed and developing countries - both South Korea and Viet Nam.

Moreover, Palvia (1998) suggested that as globalization is becoming increasingly prevalent in the world today, many factors such as culture, politics, and economics may influence the applicability of management theories. Concurrently, according to Khaslavsky (1998) this increasingly global market, vendors are faced with the challenge of offering usable and useful applications to the local users. Besides, many scholars strongly support that the criteria for $\mathrm{M}$-Commerce adoption in developing countries are different 
from that of developed countries, due to cultural, security, social, political, economic, and technological aspects (Saidi, 2010; Yaseen \& Zayed, 2010). However, there is little research which has explicitly addressed the differences on the adoption of $\mathrm{M}$-Commerce between developed and developing countries and also most current practitioners have taken a superficial approach. Therefore, the second question in this study is whether the factors influencing $\mathrm{M}$-Commerce adoption differ in South Korea and Viet Nam.

The remainder of the paper unfolds as follows. First, the motivation for studying advanced mobile phone services adoption in the South Korea and Viet Nam is presented. Second, MCommerce adoption model is introduced as a starting point for the research model. We then integrate price, personal innovativeness, quality dimension and perceived of playfulness into our model. Next, we describe our method and report the results of our analysis. The paper concludes with a discussion of the results from both the South Korea and Viet Nam with implications.

\section{Literature Review and Research Hypotheses}

\subsection{Mobile Commerce in Viet Nam and South Korea}

Growth in M-Commerce is unstoppable. MCommerce is now 34\% of all E-Commerce transactions globally-based on an accurate weighting of E-Commerce market size by country. By year-end 2015, mobile share of E-Commerce transactions is forecast to reach $40 \%$ globally. ${ }^{1)}$ Therefore, understanding cross-device behavior will be the biggest challenge and opportunity for marketers, as a majority of users visit their sites via multiple devices.

In South Korea, for the first time ever, South Korea had the majority (over 50\%) of their ECommerce transactions via mobile in Q1 2015. ${ }^{2)}$ In addition, according to an analyst from TechNavio's Telecom, as smart phone penetration is increasing in South Korea, the demand for smartphone applications and services is also growing rapidly. For the purchase of these applications, consumers need to use M-Commerce. As mobile broadband connectivity is widely available in South Korea, commercial sites can be easily accessed, and therefore online purchases are also growing at a rapid pace. According to the report, high penetration rate of mobile broadband in the

1) Based on Criteo'sQ1 2015 State of Mobile Commerce Report.

2) Based on Criteo'sQ1 2015 State of Mobile Commerce Report.

vvrly corisurners use ıviudıe corrinnerce? - International Comparative Study of M-Commerce Model 67 
country, which enables easy access to the internet for conducting $\mathrm{M}$-Commerce activities, is driving the M-Commerce market in South Korea. Clearly, the development of M-Commerce in South Korea has brought both opportunities and threats for business not only in present but also in the future. To cope with this high competition, it is necessary for service providers to have better understanding of the factors impacting on the $\mathrm{M}$-Commerce adoption to make an effective strategy.

On the other hand, unlike South Korea, MCommerce practices in Viet Nam can hardly reach low-income earners that compose a majority of the population. In a market research company's report, in January 2014, only 34\% of the population in Viet Nam has access to Internet on their mobile devices and the average online time via mobile devices is $30 \%$ of the total online time which also includes desktop, laptop and other devices. Around 20\% of Viet Nam population is carrying smartphones with 95\% of smartphone users researching products via their phone." This indicates that M-Commerce in Viet Nam is in early stages of M-Commerce development in comparison with South Korea. In addition to the recent years, Vietnam's telecommunication sector has been allowed to start privatization efforts in the coming years. This fosters not only price-based competition but also service-based competition among mobile service providers. The providers are enhancing the types of service that they provide to attract more and more customers. Thus a more in-depth understanding of the factors affecting M-Commerce could help Viet Nam business stimulate faster and deeper penetration of these services and realize interest of $\mathrm{M}$-Commerce.

\subsection{M-Commerce adoption models}

Most M-Commerce articles adopted the Technology Acceptance Model (TAM) in establishing a M-Commerce adoption model (Wu \& Wang, 2005: Yang and Jolly, 2008). In studying user acceptance and use of technology, the TAM developed by Davis, (1985) to explain computerusage behavior, has been one of the cited models. O'Cass and Fenench (2003) argue that TAM is also appropriate for research areas in electronic commerce applications since electronic commerce is based on computer technology. As scholars indicate that $\mathrm{M}$-Commerce is an extension of e-commerce, it is thus justifiable to extend TAM to examine consumer intention to adopt M-Commerce. Thus, the M-Commerce adoption articles extended the TAM with new constructs aside from the original Perceived Usefulness and Perceived Ease of Use, Attitude, Intention and Actual Use constructs. Numerous studies have provided support to this model in predicting user's intention to adopt new services and

3) Seen at: http://www.ecommercemilo.com/2014/04/vietnam-ecommerce-overview-and-market-size.html \#.Vdv-Vvntnyb 
applications in different contexts (Davis et al., 1989; Igbaria and Tan, 1997; Wang et al., 2003; Gefen et al., 2003; Ikart, 2005; Wu and Wang, 2005; Cheong and Park, 2005). Recently, Faqih and Jaradat (2014) proposed a theoretical framework based on TAM3 theory and concluded that perceived usefulness and perceived ease of use are important factors to explain the individual's intention to adopt M-Commerce in Jordan. The results of these previous studies confirm that, in the mobile technology context, traditional adoption models such as TAM could be applied, but need modification and extension in order to increase their prediction and explanation power. Thus, this paper conforms to these studies, and extended TAM to analyze the usage of $\mathrm{M}$-Commerce.

\subsection{Research model and hypotheses}

\subsubsection{Hypotheses}

\section{(1) Perceived Ease of Use}

Perceived ease of use means a user-friendly device. This variable refers to the degree to which the prospective user expects the target system to be free of effort and it also refers to effective navigation tools that encourage service usage and the full exploitation of enhanced features. According to Kim et al., (2007) perceived ease of use was defined as the overall userfriendliness of using mobile devices to access the Internet, neither to M-Internet. This is be- cause M-Internet runs on limited resources compared to other systems, especially for users of mobile phone where screen size and manipulation difficulty demand mental and physical efforts.

In addition, Agarwal and Karahanna (2000) assumed that the relation between Perceived Ease of Use and Perceived Playfulness lies on the logic that the easier an individual perceives M-Internet, the more he/she is likely to consider it playful. Cheong and Park (2005) also found that perceive ease of use has an impact on Perceived Playfulness. Thus, this study proposes that individuals' perceptions of mobile device's ease of use will influence his/her perceived playfulness in using $\mathrm{M}$-Commerce.

Furthermore, for mobile phone users, convenience and ease are critical. Users would tend to consider services that are easier to use to be more useful and would be more likely to intend to use them. Therefore, it would be important to determine whether this perception will lead to their intention to use $\mathrm{M}$-Commerce. Hence we expected the following hypotheses.

H1a: Perceived ease of use significantly affects intention to use mobile commerce.

H1b: Perceived ease of use significantly affects perceived usefulness.

H1c: Perceived ease of use significantly affects perceived playfulness 
(2) Perceived usefulness

Perceived usefulness is one of the most widely studied variables in technology adoption. This has been indicated that perceived usefulness plays a vital role in the adoption of technology (Pagani, 2004; Bhatti, 2007; Kim et al., 2007). Perceived usefulness is defined as the extent to which individuals believe that using the new technology will enhance their task performance. The usefulness construct has been used extensively in information systems and technology research, and has strong empirical support as an important predictor of technology adoption (Kieran Mathieson, 1991). Other studies providing evidence of the significant effect of perceived usefulness on intention are from Davis et al., (1989); Venkatesh and Morris (2000). The ultimate reason for people to utilize M-Commerce is that they find it useful to their tasks, transactions or everyday living. An individual evaluates the consequences of their behavior in terms of perceived usefulness and base their choice of behavior on the desirability of the perceived usefulness. Hence, we posit that

H2a: Perceived usefulness significantly affects intention to use mobile commerce.

H2b: Perceived usefulness significantly affects $M$-Commerce usage

(3) Perceived Playfulness

Perceived playfulness refers to an individual's subjective experience of human-computer in- teraction (Moon \& Kim, 2001). This new concept is often referred to as Fun (Pagani, 2004; Bruner \& Kumar, 2005) or Enjoyment (Nysveen et al., 2005). According to Nysveen et al., (2005), perceived enjoyment stands out as an important motive for using experiential mobile services. Perceived playfulness plays a significant role in developing the intention to use as well as the attitude toward the system (Agarwal \& Karahanna, 2000; Moon \& Kim, 2001; Teo et al.,1999). Also, Atkinson \& Kydd (1997) tested the role of usefulness and enjoyment in World Wide Web (www) usage and suggested that the perceived enjoyment significantly influences the usage of www for entertainment purposed. Moon \& Kim (2001) extended the TAM in the context of www and suggested that people use the internet not only for utilitarian perceived purposed but also for leisure and recreation. Hence, the perceived playfulness is introduced as a new variable in the understanding of $\mathrm{M}$-Commerce adoption.

Moreover, individuals who experience immediate pleasure or joy from using a technology and perceive any activity involving the technology to be personally enjoyable in its own right aside from the instrumental value of the technology, are more likely to adopt the technology and use it more extensively than others. Thus, the hypotheses are:

H3a: Perceived playfulness significantly affects intention to use. 
H3b: Perceived playfulness significantly affects $M$-Commerce usage.

\section{(4) Intention to Use}

Individual's intention to use M-Commerce affects positively the usage of M-Commerce. This was supported in previous studies that focused on the acceptance and use of new technology (Compeau and Higgins, 1995; Venkatesh and Davis, 2000; Hung et al., 2003; Yaseen and Zayed, 2010). Thus, we argue that:

H4: Intention to use significantly affects the M-Commerce usage.

(5) Perceived Cost

Cost means the monetary transaction costs when mobile phone users use $\mathrm{M}$-Commerce. Given that the cost of accessing $\mathrm{M}$-Commerce is higher than that of accessing through wirebased internet, the subscription, service and communications costs which may influence the individual's using $\mathrm{M}$-Commerce is suggested to be considered carefully. This concept can be also known as the perceived financial cost or resources and perceived fee. Mathieson et al., (2001) proposed that perceived financial resource is a significant predictor of the intention to use an IS. Also, it has been showed that perceived fee directly influences perceived value (Zeithaml, 1988; Dodds et al., 1991; Chang \& Wildt, 1994). Depending on the provider, there are different rates, extra charges for ad- vanced mobile phone services. An appropriate and acceptable $\mathrm{M}$-Commerce service charge is a key predictor of mobile users' satisfaction toward using M-Commerce.

In the development of behavioral intention, customers compare the benefit from the service to the cost of using the service. If the cost exceeds the benefit, they do not subscribe the service. Also, Wei et al stated that cost is one factor that can slow the development of $\mathrm{M}^{-}$ Commerce. It should also be noted that most of the users of mobile phones include younger students, such as university and high school students. Therefore this study hypothesizes that:

H5: Perceived cost significantly affects the M-Commerce Usage.

(6) Personal innovativeness

Perceived innovativeness is a domain-specific individual trait that reflects the willingness of a person to try out new information technology (Agarwal \& Prasad, 1998). It has long been recognized that highly innovative individuals are active information seekers about new ideas in general innovation diffusion research. They are able to cope with high levels of uncertainty and develop more positive intentions toward acceptance (Rogers, 1995). Some previous studies have explored that individuals with higher levels of innovativeness might develop more positive perceptions of usefulness, ease of use and compatibility, which in turn increases an individual's 
technology usage intention (Midgley \& Dowling, 1978; Limayem et al., 2000; Lee et al., 2007).

Furthermore, Lewis et al., (2003) found that personal innovativeness in technology significantly affected perceived usefulness and perceived ease of use. Lu et al., (2003) proposes that personal innovativeness in technology, along with a number of other factors, all determine user perceived short-term as well as long-term usefulness, and ease of use, which, in turn, influence user intention and attitude to adopt wireless Internet services via mobile technology. Since individuals with higher personal innovativeness in technology tend to be more risk-taking, it is also reasonable to expect them to develop more positive intentions toward the use of wireless Internet services via mobile technology. Thus, the innovative disposition may very well serve as the primary and direct antecedents for adoption decision, without much consideration to perceptions at all. Hence, we propose:

H6a: Personal innovativeness significantly affects perceived usefulness.

H6b: Personal innovativeness significantly affects perceived ease of use.

H6c: Personal innovativeness has a direct positive impact on intention to use.

(7) Quality dimension

DeLone \& McLean (1992) postulated a model of information system (IS) success in which "system quality" measures technical success, "information quality" measures semantic success, and "use satisfaction, individual impacts" and "organizational impacts" measure effectiveness success. Pitt et al., (1995) later argued that the measures seem strongly product-focus because service plays a vital role in IS effectiveness, they added "service quality" as another component of IS success. According to William H. DeLone \& McLean (2003) the updated model can be adapted to the measurement challenges of the B2C E-Commerce world.

In an E-Commerce system, Halawi et al., (2007) defined system quality refers to measures of the information processing system itself in terms of usability, adaptability, reliability, availability and response time. Information quality was defined as measures of IS output, namely the quality of the information that the system produces primarily in the form of reports and captures "the content issue," which means that Web content should be personalized, complete, relevant, and easy to understand (William $\mathrm{H}$. DeLone \& McLean, 2003) so in this study content quality was used instead of information quality. Finally, service quality measures the quality of the support system users receive from the IS department and IT support personnel (William H. DeLone \& McLean, 2003). Many research usually measures service quality with respect to responsiveness, assurance, and empathy (William H. DeLone \& McLean, 2003; Delone \& Mclean, 2004; Khayun et al., 2012). Lee $\&$ Chen (2014) employed the three-dimensional 
quality concept from DeLone and McLean's model and denoted that perceived information, system, and service qualities all positively influence confirmation, whereas information and system qualities affect perceived usefulness and draws attention to the importance of quality in retaining $\mathrm{M}$-Commerce customers.

Also, the fact that many retailers have seized the opportunity to go "mobile," but their sites have slow load times, out of date information as well as complicated navigation so that those enterprises were devastated. Hence, offering up to date product and service information, ensuring connection quality and providing good quality customer service seem paramount for anyone who wants to employed mobile business.

Since, the role of quality factor cannot be underestimated for M-Commerce success. Therefore, this study integrates the three dimensions of perceived quality: service quality, content quality, system quality with TAM to investigate the determinants of consumer intentions to adoption M-Commerce.

\section{1) System Quality}

Lin and Lu (2000) proposed that in information system context, system quality is especially important because individuals become reluctant to use the system when they experience frequent delay in response, lack of access, frequent disconnection and poor security. According to DeLone and McLean, (1992) the information quality and system quality are found to be im- portant constructs that bring the success of information system. In this study, we also expect that the system quality has positive impact on the perceived playfulness because better system can make individuals feel $\mathrm{M}$-Commerce more enjoyable and playful. Thus, we propose:

H7a: System quality significantly affects perceived usefulness.

H7b: System quality significantly affects perceived ease of use.

\section{2) Content Quality}

The concept of contents quality is similar to the information quality and used in the study of DeLone and McLean (1992) and Lin and $\mathrm{Lu}$ (2000) because information is often regarded as contents in the context of the Internet. With regards to this study, it is hypothesized that the contents quality has a positive influence on the perceived playfulness since better contents can make individuals feel M-Commerce to be more enjoyable and fun. According to Cheong and Park (2005) the quality of the content and the extent to which that content meets the needs and expectations of $\mathrm{M}$-Commerce users could affect their perception of its usefulness. Thus, the hypothesis:

H8a: Content quality significantly affects perceived usefulness.

H8b: Content quality significantly affects perceived playfulness. 


\section{3) Service Quality}

In this study, service quality is defined as the degree to which M-Commerce through the network and service provider can give customers prompt, promised, and professional service. Cho (2008) proposed that the service factor was a predictor of perceived ease of use in Korean context. Therefore, we argue that service quality has a relationship with perceived ease of use as follows:

H9: Service quality significantly affects the perceived ease of use.

\subsubsection{Conceptual research model}

The aim of the current study is to develop a success model for $\mathrm{M}$-Commerce adoption in Viet Nam and Korea that would explain how individuals behave in accepting or using MCommerce. The independent variables include System Quality, Content Quality, Service Quality, Personal Innovativeness and Perceived Cost factors. For mediating variables, the perceived usefulness, perceived ease of use, perceived playfulness, and intention to use are utilized in the model, as shown in the Figure 1.

〈Figure 1〉 Proposed Research Model

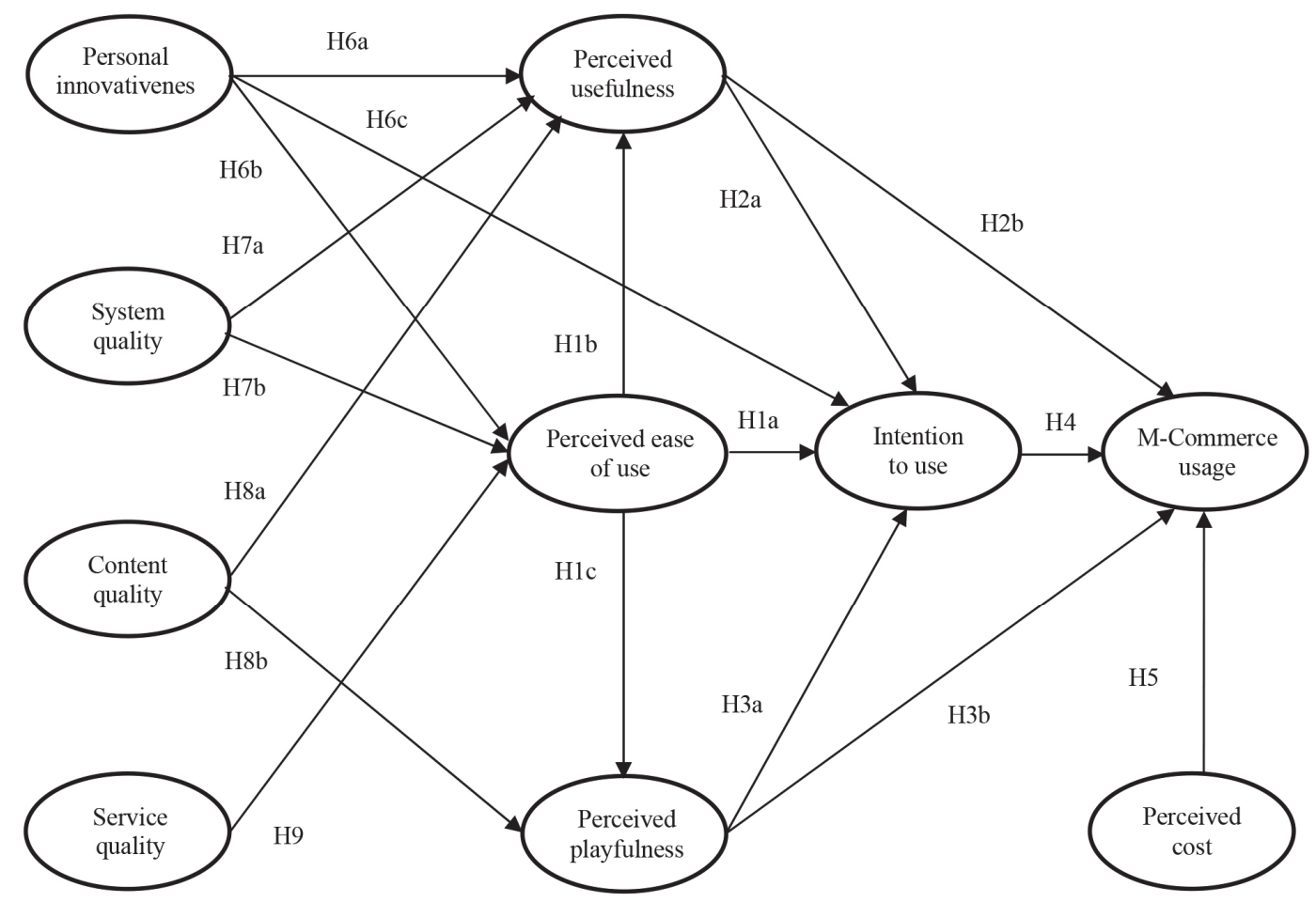

74 ASIA MARKETING JOURNAL Vol. 18 No. 03 October 2016 


\section{Method}

\subsection{Population and sample}

The data was collected by using a paper-based survey questionnaire. In Viet Nam, respondents are students from universities in Ho Chi Minh City, the principal business center of Viet Nam, and university of Da Lat in Da Lat city. In Korea, to ensure the similarity of respondents, we also collected data from students of universities in Seoul, the capital and business center of South Korea.

In addition, in this study, university students were selected since they tend to have higher technology readiness than the others. In fact, according to Jurisic \& Azevedo (2011) university students are one of the most important target markets in many high-tech products.

After gathering the answered questionnaires, they were checked thoroughly to assess the validity whether to be included in the study. Those with NO answers on the query Usage of MCommerce were excluded right away. Then, those with YES were given numbers for the data input. Among the responded cases, sample size which is used for analysis of this research in Viet Nam and South Korea is 532 respondents and 187 respondents, respectively.

\subsection{Measuring the constructs}

Questionnaires were developed to achieve closely the objectives of this study. The measurement of the questionnaire was adapted from scale items that were validated and used in previous research studies (Wu and Wang, 2005; Pedersen 2005; Wang et al., 2006; Kim et al., 2007; Davis, 1989, Cheong and Park, 2005; Yang and Folly, 2008; Delone and McLean, 2003; Faqih and Jaradat, 2014). The items were translated into Vietnamese and South Korean, then were modified based on group discussion. All items used 7- point Likert scales ranging from (1) strongly disagree to (7) strongly agree.

\section{Results}

\subsection{Demographic Results}

The respondent's demographics are summarized in Table 1. In Viet Nam, almost $57.1 \%$ of the respondents are female. The majority of the respondents ages $(64.1 \%)$ were students with age from early 20 to less than 25 years old range. Meanwhile, in South Korea, respondents are male is slightly much than female. However, like Viet Nam, respondent's age is young (20-25 years old) accounting for 85 percent. 
〈Table 1〉 Sample Demographics

\begin{tabular}{|c|c|c|c|c|c|}
\hline \multicolumn{2}{|c|}{} & \multicolumn{2}{|c|}{ Viet Nam } & \multicolumn{2}{c|}{ South Korea } \\
\cline { 2 - 6 } Demographic profile & Frequency & Percentage (\%) & Frequency & Percentage (\%) \\
\hline \multirow{4}{*}{ Gender } & Male & 228 & 42.9 & 95 & 50.8 \\
\cline { 2 - 6 } & Female & 304 & 57.1 & 92 & 49.2 \\
\cline { 2 - 6 } & Total & 532 & 100 & 187 & 100 \\
\hline \multirow{5}{*}{ Age Group } & $\langle 20$ & 89 & 16.7 & 1 & 0.6 \\
\cline { 2 - 6 } & $20-25 \mathrm{~s}$ & 341 & 64.1 & 159 & 85 \\
\cline { 2 - 6 } & $25-30 \mathrm{~s}$ & 75 & 14.1 & 16 & 8.6 \\
\cline { 2 - 6 } & $30-35 \mathrm{~s}$ & 27 & 5.1 & 11 & 5.9 \\
\cline { 2 - 6 } & Total & 532 & 100 & 187 & 100 \\
\hline
\end{tabular}

\subsection{Frequencies}

Multiple response analysis was also done to evaluate the respondent's answers in the $\mathrm{M}$ Commerce activities they frequently use. As shown in the Table 2, even though order and percentage of top five most frequent used in South Korea and Viet Nam is slightly different, but most of this activities is similar.

It can be seen from Table 3, the character- istics of mobile devices about its convenience such as "Availability of Internet access anywhere" and "Immediate access to Internet when needed" feel similar between two countries. However, the interesting thing is that objective of using $\mathrm{M}$-Commerce in Viet Nam relates function "study or work", meanwhile for South Korea it relates to "relieves boredom". This might be the reason showing interestingly difference in using M-Commerce between South

〈Table 2〉 Top five M-Commerce activities (Multiple Responses)

\begin{tabular}{|c|l|c|c|}
\hline Country & \multicolumn{1}{|c|}{ Activity } & Count & Percent \\
\hline \multirow{5}{*}{ Viet Nam } & 1.News & 371 & 69.7 \\
\cline { 2 - 4 } & 2. Instant Messaging/Chatting & 345 & 64.8 \\
\cline { 2 - 4 } & 3. Social Network (Facebook, Twitter, others) & 333 & 62.6 \\
\cline { 2 - 4 } & 4. Ticket Purchase & 297 & 55.8 \\
\cline { 2 - 4 } & 5. Downloading ringtone & 297 & 55.8 \\
\hline \hline \multirow{5}{*}{ South Korea } & 1. Social Network (Facebook, Twitter, KaTalk) & 144 & 77.0 \\
\cline { 2 - 4 } & 2. Information search and general web surfing & 139 & 74.3 \\
\cline { 2 - 4 } & 3. Weather Forecast & 117 & 62.6 \\
\cline { 2 - 4 } & 4. Instant Messaging/Chatting & 117 & 62.6 \\
\cline { 2 - 4 } & 5. News & 113 & 60.4 \\
\hline
\end{tabular}


〈Table 3〉 Top Three Motivations for Using M-Commerce

\begin{tabular}{|c|l|c|c|}
\hline Country & \multicolumn{1}{|c|}{ Reasons for using } & Count & Percent \\
\hline \multirow{4}{*}{ Viet Nam } & 1. For study or work & 286 & 53.8 \\
\cline { 2 - 4 } & 2. Availability of Internet access anywhere & 260 & 48.9 \\
\cline { 2 - 4 } & 3. Immediate access to Internet when needed & 234 & 44.0 \\
\hline \hline \multirow{3}{*}{ South Korea } & 1. Availability of Internet access anywhere & 151 & 80.7 \\
\cline { 2 - 4 } & 2. Immediate access to Internet when needed & 148 & 79.1 \\
\cline { 2 - 4 } & 3. Relieves boredom & 128 & 68.4 \\
\hline
\end{tabular}

Korea and Viet Nam.

\subsection{Measurement Assessment}

\subsubsection{Reliability Analysis}

Reliability was done to test the degree to which the set of latent construct indicators are consistent in their measurements. The reliability of the variables was assessed by the Cronbach's Alpha and Item-total Correlation. The acceptable threshold for Cronbach's Alpha is 0.70, while constructs which are highly inter-correlated indicate that they are all measuring the same latent constructs. Table 4 shows that the resulting alpha values range from 0.787 to 0.934, which are above the acceptable threshold of 0.70 . Also, the Item-total correlation test results are satisfactory.

\subsubsection{Construct Validity Analysis}

A confirmatory factor analysis was conducted to test the measurement model. This assesses

〈Table 4〉 Reliability with Cronbach's alpha

\begin{tabular}{|l|c|c|c|c|}
\hline \multirow{2}{*}{ Constructs } & \multicolumn{2}{|c|}{ Viet Nam } & \multicolumn{2}{c|}{ South Korea } \\
\cline { 2 - 5 } & Items & Cronbach's alpha & Items & Cronbach's alpha \\
\hline Personal innovativeness & 3 & 0.787 & 3 & 0.866 \\
\hline System quality & 4 & 0.839 & 4 & 0.814 \\
\hline Content quality & 3 & 0.860 & 3 & 0.801 \\
\hline Service quality & 3 & 0.870 & 3 & 0.691 \\
\hline Perceived usefulness & 3 & 0.865 & 4 & 0.919 \\
\hline Perceived ease of use & 3 & 0.863 & 3 & 0.892 \\
\hline Perceived playfulness & 4 & 0.867 & 4 & 0.933 \\
\hline Intention to use & 3 & 0.875 & 3 & 0.862 \\
\hline M-Commerce usage & 3 & 0.845 & 3 & 0.858 \\
\hline Perceived cost & 3 & 0.875 & 3 & 0.934 \\
\hline
\end{tabular}


what the construct (concept) or scale is, in fact, measuring. To construct validity, two checks have to be performed: the convergent validity and discriminant validity. Convergent validity was evaluated by examining composite reliability and average variance extracted (AVE) from the measures. Discriminant validity was evaluated by the square root of AVE for each construct is greater than the correlations between the constructs and all other constructs, indicating that these constructs have discriminant validity (Fornell \& Larcker, 1981).
All the model-fit indices exceeded their respective common acceptance levels suggested by previous research, thus demonstrating that the measurement model exhibited a good fit with the data collected in Viet Nam ( $\chi^{2}$ (419) $=799.514, \mathrm{CMIN} / \mathrm{df}=1.908, \mathrm{p}=.000 ; \mathrm{GFI}$ $=.915 ; \mathrm{CFI}=.965 ; \mathrm{RMSEA}=.041)$ mean $^{-}$ while the data in South Korea demonstrating that the measurement model exhibited a fairly good fit with the data collected $\left(x^{2}(389)=\right.$ 791.836, $\mathrm{CMIN} / \mathrm{df}=2.036, \mathrm{p}=.000 ; \mathrm{GFI}=$ .784; TLI $=.903 ; \mathrm{CFI}=.919 ;$ RMSEA $=.075)$.

〈Table 5〉 Composite reliability, AVE and correlation of constructs' values

\begin{tabular}{|c|c|c|c|c|c|c|c|c|c|c|c|c|}
\hline Viet Nam & $\mathrm{CR}$ & AVE & 1 & 2 & 3 & 4 & 5 & 6 & 7 & 8 & 9 & 10 \\
\hline 1. M-Commerce usage & 0.847 & 0.649 & 0.806 & & & & & & & & & \\
\hline 2. Usefulness & 0.868 & 0.687 & 0.728 & 0.829 & & & & & & & & \\
\hline 3. System quality & 0.841 & 0.570 & 0.628 & 0.695 & 0.755 & & & & & & & \\
\hline 4. Service quality & 0.873 & 0.696 & 0.447 & 0.556 & 0.677 & 0.834 & & & & & & \\
\hline 5. Ease of use & 0.867 & 0.686 & 0.635 & 0.638 & 0.713 & 0.602 & 0.828 & & & & & \\
\hline 6. Playfulness & 0.869 & 0.625 & 0.625 & 0.651 & 0.751 & 0.549 & 0.717 & 0.790 & & & & \\
\hline 7. Content quality & 0.861 & 0.675 & 0.597 & 0.607 & 0.734 & 0.604 & 0.653 & 0.670 & 0.821 & & & \\
\hline 8. Perceived cost & 0.874 & 0.699 & 0.465 & 0.443 & 0.573 & 0.609 & 0.469 & 0.449 & 0.662 & 0.836 & & \\
\hline 9. Intention to use & 0.876 & 0.702 & 0.786 & 0.774 & 0.688 & 0.557 & 0.708 & 0.697 & 0.667 & 0.458 & 0.838 & \\
\hline 10. P Innovativeness & 0.795 & 0.566 & 0.520 & 0.517 & 0.566 & 0.562 & 0.516 & 0.505 & 0.529 & 0.499 & 0.519 & 0.752 \\
\hline \multicolumn{13}{|l|}{ South Korea } \\
\hline 1. Ease of use & 0.900 & 0.750 & 0.866 & & & & & & & & & \\
\hline 2. P Innovativeness & 0.874 & 0.701 & 0.313 & 0.837 & & & & & & & & \\
\hline 3. Perceived cost & 0.936 & 0.831 & 0.312 & 0.101 & 0.911 & & & & & & & \\
\hline 4. Content quality & 0.805 & 0.580 & 0.797 & 0.292 & 0.419 & 0.762 & & & & & & \\
\hline 5. Service quality & 0.757 & 0.608 & 0.643 & 0.345 & 0.523 & 0.664 & 0.780 & & & & & \\
\hline 6. System quality & 0.878 & 0.706 & 0.774 & 0.266 & 0.398 & 0.860 & 0.711 & 0.840 & & & & \\
\hline 7. Intention to use & 0.859 & 0.671 & 0.762 & 0.192 & 0.312 & 0.825 & 0.670 & 0.904 & 0.819 & & & \\
\hline 8. Playfulness & 0.933 & 0.779 & 0.705 & 0.237 & 0.295 & 0.676 & 0.583 & 0.656 & 0.613 & 0.883 & & \\
\hline 9. Usefulness & 0.921 & 0.745 & 0.659 & 0.267 & 0.389 & 0.737 & 0.554 & 0.704 & 0.702 & 0.544 & 0.863 & \\
\hline 10. M-Commerce usage & 0.871 & 0.701 & 0.687 & 0.177 & 0.268 & 0.696 & 0.585 & 0.797 & 0.816 & 0.706 & 0.517 & 0.837 \\
\hline
\end{tabular}

Note: Diagonal elements are the square root of AVE. Off-diagonal elements are the correlations among constructs. 
Values for composite reliability are recommended to exceed 0.70 (Chin, Marcolin, \& Newsted, 2003) and AVE values should be greater than the generally-recognized cut-off value of 0.50 (Fornell \& Larcker, 1981). Table 5 shows that all composite reliability and AVE values of both Viet Nam and South Korea meet the recommended threshold values. Therefore, it is an evidence for convergent validity. In addition, the square root of AVE for each construct is greater than the correlations between the constructs and all other constructs, indicating that these constructs have discriminant validity, except content quality and system quality in South Korea.

\subsection{Structural Results: Hypothesis Testing}

SEM was used to test the hypotheses in South Korea and Viet Nam. The SEM results indicated that the model had an acceptable fit in Viet Nam better than in South Korea. In particularly, the indices of model with data collected in Viet Nam are $\chi^{2}(437)=875.069$, $\mathrm{CMIN} / \mathrm{df}=2.002, \mathrm{p}=.000 ; \mathrm{GFI}=.909 ; \mathrm{CFI}=$ $.960 ;$ RMSEA $=.043$ while for South Korea are $\mathrm{x}^{2}(407)=873.522, \mathrm{CMIN} / \mathrm{df}=2.146, \mathrm{p}=$ $.000 ; \mathrm{GFI}=.765 ;$ TLI $=.893 ; \mathrm{CFI}=.906$; RMSEA $=.079$.

In Viet Nam, Table 8 presents the un-

$\langle$ Table 6〉 Unstandardized structural paths

\begin{tabular}{|c|c|c|c|c|c|c|c|c|c|c|}
\hline \multirow{2}{*}{ Hypothesis } & \multicolumn{5}{|c|}{ Viet Nam } & \multicolumn{5}{|c|}{ South Korea } \\
\hline & R.E & S.E & C.R & $\mathrm{P}$ & Result & R.E & S.E & C.R & $\mathrm{P}$ & Result \\
\hline H1a: Perceived Ease of Use $\rightarrow$ Intention to Use & .266 & .071 & 3.739 & .000 & $S^{* *}$ & .565 & .096 & 5.915 & .000 & $S^{* *}$ \\
\hline H1b: Perceived Ease of Use $\rightarrow$ Perceived Usefulness & .250 & .067 & 3.744 & .000 & $S^{* *}$ & .111 & .131 & .844 & .399 & NS \\
\hline H1c: Perceived Ease of Use $\rightarrow$ Perceived Playfulness & .571 & .059 & 9.718 & .000 & $S^{* *}$ & .535 & .111 & 4.805 & .000 & $S^{* *}$ \\
\hline H2a: Perceived Usefulness $\rightarrow$ Intention to Use & .527 & .060 & 8.781 & .000 & $S^{* *}$ & .328 & .073 & 4.516 & .000 & $S^{* *}$ \\
\hline H2b: Perceived Usefulness $\rightarrow$ M-Commerce Usage & .308 & .077 & 3.994 & .000 & $\mathrm{~S}^{* * *}$ & -.217 & .087 & -2.486 & .013 & NS \\
\hline H3a: Perceived Playfulness $\rightarrow$ Intention to Use & .212 & .056 & 3.804 & .000 & $S^{* * *}$ & .042 & .072 & .581 & .562 & NS \\
\hline H3b: Perceived Playfulness $\rightarrow$ M-Commerce Usage & .084 & .057 & 1.475 & .140 & NS & .381 & .069 & 5.505 & .000 & $S^{* *}$ \\
\hline H4: Intention to Use $\rightarrow$ M-Commerce Usage & .508 & .079 & 6.442 & .000 & $\mathrm{~S}^{* * *}$ & .847 & .109 & 7.796 & .000 & $S^{* *}$ \\
\hline H5: Perceived Cost $\rightarrow$ M-Commerce Usage & .085 & .043 & 1.991 & .047 & $S^{*}$ & .005 & .048 & .099 & .921 & NS \\
\hline H6a: P. Innovativeness $\rightarrow$ Perceived Usefulness & .129 & .056 & 2.315 & .021 & $S^{*}$ & .040 & .063 & .636 & .525 & NS \\
\hline H6b: P. Innovativeness $\rightarrow$ Perceived Ease of Use & .120 & .055 & 2.179 & .029 & $S^{*}$ & .089 & .056 & 1.607 & .108 & NS \\
\hline H6c: P. Innovativeness $\rightarrow$ Intention to Use & .079 & .053 & 1.485 & .138 & NS & -.089 & .054 & -1.656 & .098 & NS \\
\hline H7a: System Quality $\rightarrow$ Perceived Usefulness & .412 & .107 & 3.866 & .000 & $S^{* * *}$ & .267 & .291 & .917 & .359 & NS \\
\hline H7b: System Quality $\rightarrow$ Perceived Ease of Use & .671 & .079 & 8.530 & .000 & $S^{* * *}$ & .891 & .118 & 7.528 & .000 & $S^{* *}$ \\
\hline H8a: Content Quality $\rightarrow$ Perceived Usefulness & .130 & .063 & 2.058 & .040 & $S^{*}$ & .616 & .265 & 2.328 & .020 & $S^{*}$ \\
\hline H8b: Content Quality $\rightarrow$ Perceived Playfulness & .379 & .051 & 7.457 & .000 & $S^{* * *}$ & .406 & .143 & 2.833 & .005 & $S^{*}$ \\
\hline H9: Service Quality $\rightarrow$ Perceived Ease of Use & .139 & .055 & 2.551 & .011 & $S^{*}$ & .099 & .116 & .856 & .392 & NS \\
\hline
\end{tabular}

Note: *: significant at $\mathrm{P}<.05$; **: significant at $\mathrm{P}<.000$; $\mathrm{S}$ : Support; NS: Not support: $\mathrm{P}$ : $\mathrm{P}$-value 
〈Figure 2a〉 Results of testing hypotheses - Viet Nam

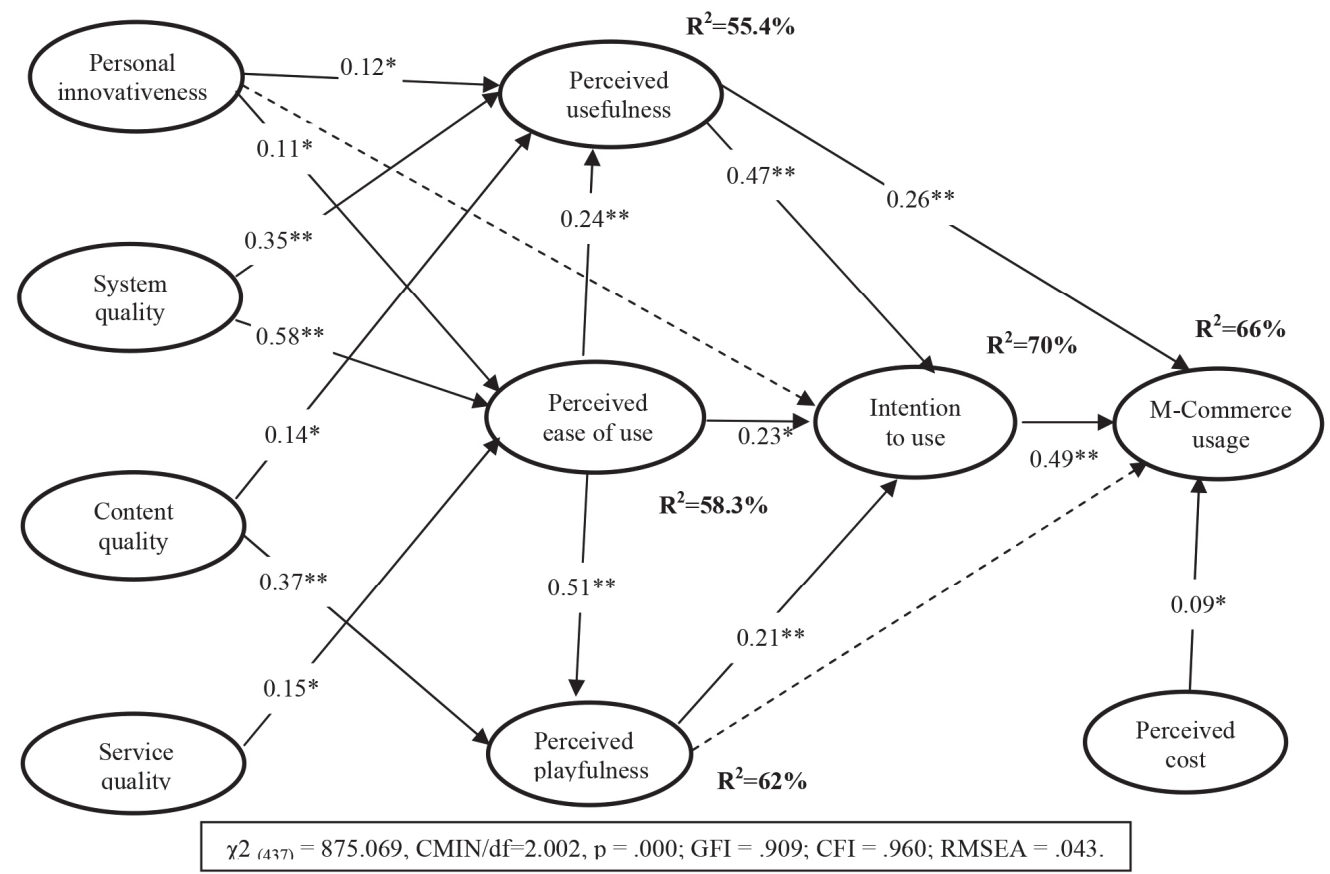

〈Figure 2b〉 Results of testing hypotheses - South Korea

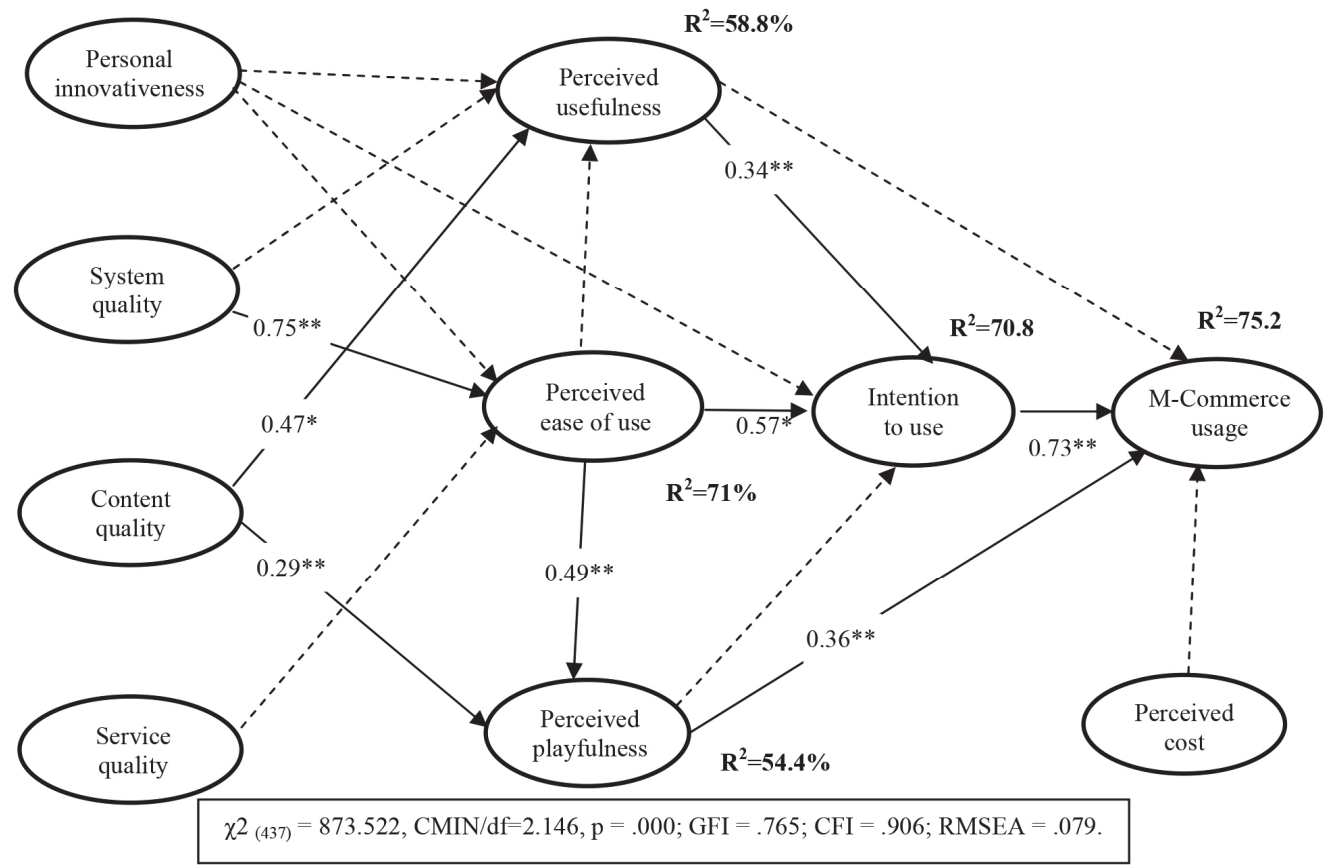

80 ASIA MARKETING JOURNAL Vol. 18 No. 03 October 2016 
standardized structural paths; and Figure 2a presents the significant structural relationship among the research variables and the standardized path coefficients with their respective significance levels. Only 2 of 17 hypotheses proposed are found insignificant (H3b, H6c). In addition, the Figure 2 shows the model explained substantial variance in both perceived usefulness $\left(R^{2}=55.4 \%\right)$ and intention to use $\left(R^{2}=70 \%\right)$, perceived ease of use $\left(R^{2}=58.3 \%\right)$, perceived of playfulness $\left(\mathrm{R}^{2}=62 \%\right)$ and $\mathrm{M}^{-}$ Commerce usage $\left(\mathrm{R}^{2}=66 \%\right)$.

In South Korea, there are nine hypotheses proposed which are found insignificant (Table 6). In addition, the Figure $2 \mathrm{~b}$ shows the model explained substantial variance in both perceived usefulness $\left(R^{2}=58.8 \%\right)$ and intention to use $\left(R^{2}=70.8 \%\right)$, perceived ease of use $\left(R^{2}=71 \%\right)$, perceived of playfulness $\left(\mathrm{R}^{2}=54.4 \%\right)$ and $\mathrm{M}^{-}$ Commerce usage $\left(\mathrm{R}^{2}=75.2 \%\right)$.

\section{Conclusions and Implications}

This study identified various factors affecting mobile commerce adoption based on existing literature and developed a comprehensive model of mobile commerce adoption. After developing and validating a research instrument, the model

〈Table 7〉 Comparison of Results: Viet Nam versus South Korea

\begin{tabular}{|l|c|c|}
\hline \multirow{2}{*}{ Hypotheses } & \multicolumn{2}{|c|}{ Results } \\
\cline { 2 - 3 } & Viet Nam & South Korea \\
\hline H1a: Perceived Ease of Use $\rightarrow$ Intention to Use & Accept & Accept \\
\hline H1b: Perceived Ease of Use $\rightarrow$ Perceived Usefulness & Accept & Reject \\
\hline H1c: Perceived Ease of Use $\rightarrow$ Perceived Playfulness & Accept & Accept \\
\hline H2a: Perceived Usefulness $\rightarrow$ Intention to Use & Accept & Accept \\
\hline H2b: Perceived Usefulness $\rightarrow$ M-Commerce Usage & Accept & Reject \\
\hline H3a: Perceived Playfulness $\rightarrow$ Intention to Use & Accept & Reject \\
\hline H3b: Perceived Playfulness $\rightarrow$ M-Commerce Usage & Reject & Accept \\
\hline H4: Intention to Use $\rightarrow$ M-Commerce Usage & Accept & Accept \\
\hline H5: Perceived Cost $\rightarrow$ M-Commerce Usage & Accept & Reject \\
\hline H6a: P. Innovativeness $\rightarrow$ Perceived Usefulness & Accept & Reject \\
\hline H6b: P. Innovativeness $\rightarrow$ Perceived Ease of Use & Accept & Reject \\
\hline H6c: P. Innovativeness $\rightarrow$ Intention to Use & Reject & Reject \\
\hline H7a: System Quality $\rightarrow$ Perceived Usefulness & Accept & Reject \\
\hline H7b: System Quality $\rightarrow$ Perceived Ease of Use & Accept & Accept \\
\hline H8a: Content Quality $\rightarrow$ Perceived Usefulness & Accept & Accept \\
\hline H8b: Content Quality $\rightarrow$ Perceived Playfulness & Accept & Accept \\
\hline H9: Service Quality $\rightarrow$ Perceived Ease of Use & Accept & Reject \\
\hline
\end{tabular}


was applied in two different cultural contexts: South Korea and Viet Nam. As expected, differences were found between the South Korean and Vietnamese M-Commerce consumers in regard to $\mathrm{M}$-Commerce adoption. Nine out of seventeen links in the research model were different across the two cultures.

In Viet Nam, our model was able to explain $66 \%$ of the variance in the consumer behavioral M-Commerce adoption. The relationships of the TAM model are supported by our study. Both perceived usefulness and perceived ease of use have significant impact on consumers' M-Commerce usage (Venkatesh et al, 2000). Additionally, our study added perceived cost, personal innovativeness and quality dimensions, all of these factors play as important antecedents of Vietnamese consumer's M-Commerce usage. Our results suggest that the Vietnamese people consider the functional characteristics, usefulness, ease of use and the price before making decision to use M-Commerce.

In South Korea, the model explained 75.2\% of the variance and provided different sets of relationships compared to the Viet Nam sample. Perceived playfulness is highlighted as influencing directly to M-Commerce usage. It appears that consumers in South Korea emphasize the playfulness, hedonic characteristics before adopting $\mathrm{M}$-commerce. There was a lack of supports for one of the TAM relationships that is the impact of perceived ease of use on the perceived usefulness. However, there are several studies in the past which have failed to establish this relationship. Besides, it is interestingly that personal innovativeness has no impact on both perceived usefulness and perceived ease of use and system quality does not impact on the perceived usefulness as well as service quality is not the predictor of perceived ease of use. The reason might be that for the developed country such as in the South Korea with advanced telecommunication infrastructure and experienced society, system quality and service quality, personal innovativeness are possibly no longer affect to perceived usefulness and perceives ease of use. Furthermore, it is notably worthy is the relationship of perceived cost and M-Commerce usage is insignificant that is absolutely contrast with the results found in Viet Nam context. This difference found in South Korea and Viet Nam can be attributed to the disparity in economic environments. While price did not affect the Korean consumers, perceived high cost of mobile commerce did lead to a low level to use M-Commerce for Vietnamese consumers. In fact, high cost may well be the key obstacle to adopt M-Commerce in Viet Nam.

Interestingly, the finding of this study showed that when considering actual M-Commerce using, the perceived usefulness influence directly M-Commerce usage in Viet Nam meanwhile perceived playfulness influence directly M-Commerce usage in South Korea. It can be explained that in Viet Nam context when M-Commerce is in 
early stage, the cost for accessing internet via mobile phone is still high in relation to Vietnamese's income. Therefore, when they consider actual using M-Commerce, cost and usefulness are more important than playfulness event thought playfulness still play a vital role in intention to use M-Commerce. It means that playfulness influence indirectly on $\mathrm{M}$-Commerce usage through intention to use ( $\mathrm{H} 3 \mathrm{a}, \beta=0.21)$, which is consistent with previous study (H. Y. Wang \& Wang , 2008; Zhang et al., 2012). On the other hands, for developed, advanced telecommunication country and high income per person like South Korea, cost for accessing internet via mobile phone is very low and event free in many public zones, therefore when considering actual MCommerce usage, cost factor has no effect on M-Commerce adoption. In addition, for South Korean customer perceived playfulness influences directly on $\mathrm{M}$-Commerce usage meanwhile perceived usefulness only influence indirectly through intention to use $(\mathrm{H} 2 \mathrm{a}, \beta=0.34)$.

\subsection{Managerial Implications}

The research also brought some implication for $\mathrm{M}$-Commerce providers, operators whose purpose is promoting $\mathrm{M}$-Commerce adoption of customers.

First of all, for practitioners, this study is to help mobile business vendors identify and target consumers who have a strong intention to adopt new applications and services in $\mathrm{M}^{-}$
Commerce. The idea that M-Commerce should be provided to all customers for all products and services is too broad and risky to formulate efficient marketing strategies. Companies should continue to evaluate how individual products and services should be offered for specific consumer groups based on their individual characteristics (Frolick and Chen, 2004). Our study demonstrates that various factors need to be taken into account carefully to figure out target mobile consumers in the two different contexts.

Secondly, our study provides managers of MCommerce services whose purpose is entering the Vietnamese and South Korean marketplace specific information about users' intention to use $\mathrm{M}$-Commerce services based on individual characteristics. It informs managers' decisions on delivering targeted campaigns and specific M-Commerce services for the Vietnamese and Korean consumers. Conversely, for those with low intention to use, the implication for the business is to determine if alternative pricing strategies or new functions or hedonic characteristic should be used.

In Viet Nam, M-Commerce market developers and practitioners might make some influence on customers' M-Commerce adoption are the cost of the service and perceived usefulness factors whereas in South Korea, the factor perceived playfulness plays a vital role in promoting the customer engage in using $\mathrm{M}$-Commerce service. Therefore, web vendors would be well advised to develop their offerings and programs 
in relation to these factors and target their marketing campaigns accordingly.

In fact, compared to other shopping media, mobile commerce makes consumer feel more convenient and convenience may be a significant motivating factor. However, in Viet Nam, MCommerce development is still in early stages and consumers are more familiar with traditional offline shopping. This requires that business vendors create more convenient, useful as well as more secure mobile shopping channel in order to help customers establish the good experience of mobile commerce. Furthermore, since the $3 \mathrm{G}$ service fee in Viet Nam is still high in comparison with Vietnamese income, the customers seem more sensitive to the price so that price strategy will be become more important Marketing strategies in Viet Nam setting.

However, for a developed country, advanced telecommunication system like South Korea and with the high income of Korean the internet subscriber fee seems not to be the big problem, so the competition in $\mathrm{M}$-Commerce industry does not stop at price strategy it might move to higher level, that is the added value like playfulness besides the usefulness and ease of use. Hence, for South Korea context, M-Commerce service providers should emphasize on the playfulness factor to get more competitive advantages to win in this fierce battle.

Finally, for academics, this study contributes to the literature on $\mathrm{M}$-Commerce adoption by identifying characteristics of the M-Commerce consumers in South Korea and Viet Nam and their intention behavior to adopt M-Commerce services. Besides, the comparison between Vietnamese and Korean marketplace would be very meaningful for researchers and managers to localize M-Commerce strategy recommendations.

\subsection{Limitations and Future Researches}

Our study makes significant research contributions in a number of ways. However, some limitations need to be noted. Firstly, the sample in this research is convenient sample and the sample proportion of Viet Nam is much more than South Korean sample. Thus, generalizability of the results might be limited to Viet Nam and South Korea or countries and cultures those are the same.

This study also provides light on future research directions. In this research, the authors did not include the "security" construct in our research model because of measure difficulty so a sound operationalization should be developed and consider the security issue in the future research. Moreover, it is also interesting if our research is integrated with trust issues in MCommerce adoption to expand the current study. 〈Received October 15. 2016〉 $\langle$ Revised October 30. 2016〉 〈Accepted October 30. 2016〉 


\section{References}

Agarwal, R., \& Karahanna, E. (2000). Time Flies When You're Having Fun: Cognitive Absorption and Beliefs about Information Technology Usage. MIS Quarterly, 24, 665. Agarwal, R., \& Prasad, J. (1998). A Conceptual and Operational Definition of Personal Innovativeness in the Domain of Information Technology. Information Systems Research, 9, 204-215.

Atkinson, M., \& Kydd, C. (1997). Individual Characteristics Associated with World Wide Web Use: An Empirical Study of Playfulness and Motivation. Data Base For Advances In Information Systems, 28(2), 53-62.

Bhatti, T. (2007). Exploring Factors Influencing the Adoption of Mobile Commerce. Journal of Internet Banking and Commerce, 12, $1-13$.

Bruner, G. C., \& Kumar, A. (2005). Explaining consumer acceptance of handheld Internet devices. Journal of Business Research, 58 (5), 553-558.

Chang, T.-Z., \& Wildt, A. R. (1994). Price, Product Information, and Purchase Intention: An Empirical Study. Journal of the Academy of Marketing Science.

Chin, W. W., Marcolin, B. L., \& Newsted, P. R. (2003). A Partial Least Squares Latent Variable Modeling Approach for Measuring
Interaction Effects: Results from a Monte Carlo Simulation Study and an ElectronicMail Emotion/Adoption Study. Information Systems Research.

Cho, Y. C. (2008). Assessing User Attitudes Toward Mobile Commerce In The U.S. Vs. Korea: Implications For M-Commerce CRM. Journal of Business \& Economics Research, 6(2), 91-102.

Chuan-Chuan Lin, J., \& Lu, H. (2000). Towards an understanding of the behavioural intention to use a web site. International Journal of Information Management.

Compeau, D., \& Higgins, C. (1995). Computer Self-Efficacy: Development of a Measure and Initial Test. MIS Quarterly, 19, 189211.

Crabbe, M., Standing, C., Standing, S., \& Karjaluoto, H. (2009). An adoption model for mobile banking in Ghana. International Journal of Mobile Communications, 7(5), 515.

Davis, F. D. (1986). A technology acceptance model for empirically testing new end-user information systems: Theory and results. Management.

Davis, F. D., Bagozzi, R. P., \& Warshaw, P. R. (1989). User Acceptance of Computer Technology : A Comparison of Two Theoritical Models. Management Science, 35, 982.

DeLone, W. H., \& McLean, E. R. (1992). Information Systems Success: The Quest for the Dependent Variable. Information 
Systems Research, 3(1), 60-95.

Delone, W. H., \& Mclean, E. R. (2004). Measuring e-Commerce Success : Applying the DeLone \& McLean Information Systems Success Model. International Journal of Electronic Commerce, 9(1), 31-47.

Dodds, W. B., Monroe, K. B., \& Grewal, D. (1991). Effects of Price, Brand, and Store Information on Buyers' Product Evaluations. Journal of Marketing Research, 28(3), 307.

Faqih, K. M. S., \& Jaradat, M.-I. R. M. (2014). Assessing the moderating effect of gender differences and individualismcollectivism at individual-level on the adoption of mobile commerce technology: TAM3 perspective. Journal of Retailing and Consumer Services, 22, 37-52.

Fornell, C., \& Larcker, D. F. (1981). Evaluating Structural Equation Models with Unobservable Variables and Measurement Error. Journal of Marketing Research (JMR). Feb1981, 18, 39-50.

Gefen, D., Karahanna, E., \& Straub, D. (2003). Trust and TAM in online shopping: an integrated model. MIS Quarterly, 27, 5190.

Halawi, L. A., McCarthy, R. V, \& Aronson, J. E. (2007). AN EMPIRICAL INVESTIGATION OF KNOWLEDGE MANAGEMENT SYSTEMS' SUCCESS. Journal of Computer Information Systems, 48(2), 121-135.

Ho Cheong, J., \& Park, M. (2005). Mobile internet acceptance in Korea. Internet $\mathrm{Re}^{-}$ search, 15(2), 125-140.

Hung, S.-Y., Ku, C.-Y., \& Chang, C.-M. (2003). Critical factors of WAP services adoption: an empirical study. Electronic Commerce Research and Applications, 2 (1), 42-60.

Igbaria, M., \& Tan, M. (1997). The consequences of information technology acceptance on subsequent individual performance. Information \& Management.

Ikart, E. M. (2005). Executive Information Systems and the Top-Officers' Roles: an exploratory study of user-behaviour model and lessons learnt. Australasian Journal of Information Systems, 13, 78-100.

Junglas, I. a., \& Watson, R. T. (2008). Locationbased services. Communications of the ACM, 51(3), 65-69.

Jurisic, B., \& Azevedo, A. (2011). Building customer-brand relationships in the mobile communications market: The role of brand tribalism and brand reputation. Journal of Brand Management, 18(4-5), 349-366.

Khaslavsky, J. (1998). Integrating culture into interface design. CHI 98 Conference Summary on Human Factors in Computing Systems, (April), 365-366.

Khayun, V., Ractham, P., \& Firpo, D. (2012). Assessing e-excise success with Delone and McLean's model. Journal of Computer Information Systems, 52(3), 31-40.

Kim, H.-W., Chan, H. C., \& Gupta, S. (2007). Value-based Adoption of Mobile Internet: 
An empirical investigation. Decision Support Systems, 43(1), 111-126.

Lee, H.-M., \& Chen, T. (2014). Perceived Quality As a Key Antecedent in Continuance Intention on Mobile Commerce. International Journal of Electronic Commerce Studies, 5(2), 123-142.

Lee, W. J., Kim, T. U., \& Chung, J. (2007). User acceptance of the mobile internet. Interacting with Computers, 19(4), 472-483.

Lewis, W., Agarwal, R., \& Sambamurthy, V. (2003). Sources of influence on beliefs about information technology use: an empirical study of knowledge workers. MIS Quarterly, 27, 657-678.

Limayem, M., Khalifa, M., \& Frini, A. (2000). What makes consumers buy from Internet? A longitudinal study of online shopping. IEEE Transactions on Systems, Man, and Cybernetics Part A:Systems and Humans., 30(4), 421-432.

Lu, J., Yu, C.-S., Liu, C., \& Yao, J. E. (2003). Technology acceptance model for wireless Internet. Internet Research: Electronic Networking Applications and Policy, 13, 206222.

M. Khalifa, Cheng, S., \& Shen, K. (2012). Adoption of Mobile Commerce: A Confidence Model. Computer Information System. Mao, E., Srite, M., Thatcher, J. B., \& Yaprak, O. (2005). A Research Model for Mobile Phone Service Behaviors: Empirical Validation in the US and Turkey. Journal of
Global Information Technology Management, 8(4), 7-28.

Mathieson, K. (1991). Predicting user intentions: Comparing the technology acceptance model with the theory of planned behavior. Information Systems Research, 2, 173-191.

Mathieson, K., Peacock, E., \& Chin, W. W. (2001). Extending the technology acceptance model: The influence of perceived user resources. Database for Advances in Information Systems, 32(3), 86-112.

Midgley, D. F., \& Dowling, G. R. (1978). The Innovativeness : The Concept and Its Concept Measurement. Journal of Consumer Research, 4(4), 229-242.

Moon, J. W., \& Kim, Y. G. (2001). Extending the TAM for a World-Wide-Web context. Information and Management, 38, 217-230.

Nysveen, H., Pedersen, P. E., \& Thorbjørnsen, H. (2005). Explaining intention to use mobile chat services: moderating effects of gender. Journal of Consumer Marketing.

Nysveen, H., Pedersen, P. E., \& Thorbjørnsen, H. (2005). Intentions to Use Mobile Services: Antecedents and Cross-Service Comparisons. Journal of the Academy of Marketing Science, 33(3), 330-346.

Pagani, M. (2004). Determinants of adoption of third generation mobile multimedia services. Journal of Interactive Marketing.

Palvia, P. (1998). Global Information Technology Research: Past, Present And Future. Journal of Global Information Technology 
Management, 1(2), 3-14.

Pitt, L. F., Watson, R. T., \& Kavan, C. B. (1995). Service Quality: A Measure of Information Systems Effectiveness. MIS Quarterly, 19(2), 173-187.

Rogers, E. M. (1995). DIFFUSION of INNOVATIONS. In Elements of Diffusion (pp. 1-20).

Saidi, E. (2010). Towards a faultless mobile commerce implementation in Malawi. Journal of Internet Banking and Commerce, 15(1), 1-11.

Stafford, T. F., \& Gillenson, M. L. (2003). Mobile commerce: what it is and what it could be. Communications of the ACM, 46(12), 33-34.

Teo, T. S. ., Lim, V. K. ., \& Lai, R. Y. . (1999). Intrinsic and extrinsic motivation in Internet usage. Omega: The International Journal of Management Science, 27, 25-37.

Wang, H. Y., \& Wang, Y. S. (2008). Gender differences in the perception and acceptance of online games. British Journal of Educational Technology, 39(5), 787-806.

Wang, Y.-S., Wang, Y.-M., Lin, H.-H., \& Tang, T.-I. (2003). Determinants of user acceptance of Internet banking: an empirical study. International Journal of Service Industry Management.
William H. DeLone, \& McLean, E. R. (2003). The DeLone and McLean Model of Information Systems Success : A Ten-Year Update. Journal of Management Information System, 19, 9-31.

Wu, J.-H. H., \& Wang, S.-C. C. (2005). What drives mobile commerce? An empirical evaluation of the revised technology acceptance model. Information \& Management, 42, 719-729.

Yang, K., \& Jolly, L. D. (2008). Age cohort analysis in adoption of mobile data services: gen Xers versus baby boomers. Journal of Consumer Marketing.

Yaseen, S. G., \& Zayed, S. (2010). Exploring critical determinants in deploying mobile commerce technology. American Journal of Applied Sciences, 7(1), 120-126.

Zeithaml, V. A. (1988). Consumer Perceptions of Price, Quality, and Value: A MeansEnd Model and Synthesis of Evidence. Journal of Marketing, 52(July), 2-22.

Zhang, L., Zhu, J., \& Liu, Q. (2012). A metaanalysis of mobile commerce adoption and the moderating effect of culture. Computers in Human Behavior, 28, 1902-1911. 